\title{
Live-trapping Ocelots (Leopardus pardalis): traps, baits, injuries, immobilization and costs
}

\author{
Cynthia Elisa Widmer', Miriam Lúcia Lages Perilli, ${ }^{2,5}$ Eliana Reiko Matushima ${ }^{3}$ \& Fernando Cesar Cascelli Azevedo ${ }^{4,5 *}$ \\ ${ }^{1}$ Universidade de São Paulo, Escola Superior de Agricultura Luiz de Queiroz, Piracicaba, SP, Brazil \\ ${ }^{2}$ Universidade Federal de Viçosa, Programa de Pós-Graduação em Ecologia, Viçosa, MG, Brazil \\ ${ }^{3}$ Universidade de São Paulo, Fundação Parque Zoológico de São Paulo, São Paulo, SP, Brazil \\ ${ }^{4}$ Universidade Federal de São João del-Rei, Departamento de Ciências Naturais, São João del-Rei, Minas Gerais, \\ Brazil \\ ${ }^{5}$ Instituto Pró-Carnívoros, Atibaia, SP, Brazil \\ *Corresponding author: Fernando Cesar Cascelli Azevedo,e-mail:fazevedo@ufsj.edu.br
}

WIDMER, C.E., PERILli, M.L., MATUSHIMA, E.R., AZEVEDO, F.C.C. Live-trapping Ocelots (Leopardus pardalis): traps, baits, injuries, immobilization and costs. Biota Neotropica. 17(1): e20150125. http://dx.doi. org/10.1590/1676-0611-BN-2015-0125

\begin{abstract}
The capture of wild animals can provide important information on community structure, population dynamics, home range size, activity patterns, habitat use, denning, social behavior and health status. The objective of this study was to describe the method of capture with details on baits, injuries, non-target captures, anesthesia and costs, to evaluate its success as part of a health evaluation program of ocelots in a Brazilian Atlantic Forest Reserve. From a total of 1,011 trap-night effort in 86 days, we had 68 capture events composed of ocelots $(22 \%, n=15)$ and non-target species $(78 \%, \mathrm{n}=53)$. We captured 10 individual ocelots in 15 capture events, corresponding to 5.7 days to capture one ocelot. Capture efficiency was 14.8 ocelots/1,000 trap-nights effort. We suggest capture methods should be selected and implemented based on the following criteria: (i) high capture efficiency; (ii) high selectivity; (iii) low injury rate; (iv) high immobilization suitability; and (v) low costs, in order to enable comparisons of studies from different research groups and from different study areas, allowing a deliberate choice of the best method.
\end{abstract}

Keywords: Atlantic forest, Brazil, capture cost, capture efficiency, capture selectivity, injury rate.

\section{Captura de jaguatiricas (Leopardus pardalis): armadilhas, iscas, ferimentos, imobilização e custos}

Resumo: A captura de animais selvagens é capaz de proporcionar informações importantes acerca da estrutura da comunidade, dinâmica populacional, tamanho das áreas de vida, uso dos hábitats, locais de toca, comportamento social e estado de saúde. Este estudo teve como objetivo descrever o método de captura enfatizando as iscas utilizadas, ferimentos, capturas de espécies não-alvo, anestesia e custos, para avaliar o sucesso de captura como parte de um programa de avaliação de saúde de jaguatiricas numa reserva de Mata Atlântica no Brasil. De um de esforço total de 1.011 armadilhas-noite em 86 dias, nós tivemos 68 eventos de captura compostos de jaguatiricas $(22 \%, n=15)$ e espécies não-alvo $(78 \%$, $\mathrm{n}=53$ ). Nós capturamos 10 indivíduos diferentes em 15 eventos de captura, correspondendo a 5,7 dias para capturar uma jaguatirica. A eficiência de captura foi de 14,8 jaguatiricas/1.000 armadilhas-noite. Nós sugerimos que os métodos de captura deveriam ser selecionados e implementados com base nos seguintes critérios: (i) alta eficiência de captura; (ii) alta seletividade; (iii) baixa taxa de ferimentos; (iv) alta adequação de imobilização; e (v) baixos custos, de forma a viabilizar comparações de estudos de diferentes grupos e diferentes áreas, permitindo a escolha do melhor método.

Palavras-chave: Brasil, custo de captura, eficiência de captura, Mata Atlântica, seletividade de captura, taxa de ferimentos. 


\section{Introduction}

The ecological importance of wild felids as top predator and therefore as ecosystems regulators is recognized worldwide (Terborgh et al. 2001). However, due to their secretive behavior, these animals are difficult to capture and its capture is expensive (Barea-Azcón et al. 2006; McCarthy et al. 2013), which may explain the increasing use of remote camera-trapping in recent carnivore ecological research (Dillon \& Kelly 2008). Despite being useful and cost-effective for a wide range of objectives, non-invasive techniques may provide limited information on community structure, population dynamics, home range size, activity patterns, habitat use, denning, social behavior and health status (Deem et al. 2001; Kolbe et al. 2003; Michalski et al. 2007). Considering the advantages of capturing and handling carnivore species to perform ecological and health survey, humane and efficient live-trapping are the best methods to be used (Mowat et al. 1994).

Despite a proliferation of studies evaluating mammal trap efficiency and related injuries in the 1990s (Mowat et al. 1994), very few have been published targeting capture methods of carnivores in tropical forests (Michalski et al. 2007; McCarthy et al. 2013). With few exceptions (i.e. McBride-Jr \& McBride 2007), most peer-reviewed ecological studies on neotropical carnivores that used live-trapping methods focused on monitored animals, without providing details on the methods of trapping, injuries and anesthetic doses and responses (i.e. Emmons 1988; Crawshaw \& Quigley 1989; Harveson et al. 2004; Haines et al. 2005; Dillon \& Kelly 2008). This is also true for epidemiological studies, which focus mainly on pathogens surveys (i.e. Filoni et al. 2006; Fiorello et al. 2007; Metzger et al. 2008; Jorge et al. 2010; Widmer et al. 2011).

Most carnivore species occur at low densities and require a large amount of capture effort for success (Logan et al. 2009). In tropical forests, carnivores are often listed as threatened, as well as the non-target species that eventually may be also captured (McCarthy et al. 2013). Therefore, before considering the capture of these animals, efforts should be made towards increasing efficiency and selectivity, reducing injuries and finding a suitable immobilization protocol at reasonable cost-effectiveness (Mowat et al. 1994; Austin et al. 2004; McBride-Jr \&McBride 2007; McCarthy et al. 2013)

The ocelot (Leopardus pardalis) is a medium sized felid (adult weight ranges from 7 to $16 \mathrm{~kg}$ ), distributed from Mexico to Northeast Argentina (IUCN 2015) that is listed on CITES's Appendix I (CITES 2013) and considered Least Concern by IUCN (2015). Across its distribution, ocelots are often considered an abundant carnivore, reaching densities as high as 95 ocelots $/ 100 \mathrm{~km}^{2}$ (Kolowski \& Alonso 2010). To date there is a paucity of published data on capturing and handling free-ranging ocelots and no study has been performed focusing specifically on the evaluation of methods of trapping and the capturability of this wild felid. The objective of this study was to describe the method of capture with details on trapping methods, baits, injuries, non-target species captures, anesthesia and costs, in order to evaluate its success. This research was part of a health evaluation program of ocelots in a Brazilian Atlantic Forest Reserve (Widmer et al. 2016).

\section{Material and Methods}

\section{Study area}

This study was conducted at Rio Doce State Park (RDSP, 19'29'24" $19^{\circ} 48^{\prime} 18^{\prime \prime} \mathrm{S}$ and $\left.42^{\circ} 28^{\prime} 18^{\prime \prime}-42^{\circ} 38^{\prime} 30^{\prime \prime} \mathrm{W}\right)$, the largest Atlantic Forest patch of Minas Gerais State, Brazil (Lima-Bittencourt et al. 2011). RDSP is composed by $360 \mathrm{~km}^{2}$ of semi-deciduous seasonal tropical forest and is surrounded by Eucalyptus plantations, pastures and cities (da Silva Júnior et al. 2009). Three different areas of RDSP were surveyed during this study using the following criteria: easy access, reports of park rangers about the presence of wild carnivores and distance away from cities.

\section{Trap and baits}

Trap effort was calculated multiplying the number of traps by the number of days that traps were opened in the field. Between 2012 and 2013, we conducted eight periods of captures of approximately 10 days each. The number of traps set per night varied between two and 15, with an average of 12.5. We set the traps along dirt roads, well-traveled trails or inside the forest, with a mean distance of 396 meters between traps in each area (Figure 1). We used 15 foldable galvanized mesh cage traps with single door, triggered by treadle, size $115 \times 40 \times 60 \mathrm{~cm}$ and $12.2 \mathrm{Kg}$ weight (Gabrisa Ambiental, Cafelândia - SP, Brazil) (Figure 2). We used nylon mason line between trigger and treadle instead of the provided steel cable, and inserted plastic seals between the back and superior walls, and between lateral and superior walls to steady the trap. We covered the top of all traps with a black plastic sheet to protect bait and captured animals from sun, rain and wind. All traps were checked daily from 6 to 8 a.m. We used seven different baits. In the first capture season we used bacon, bacon and sardine and roasted chicken. For live-baits, we used chicks and quails from nearby agricultural suppliers. We adapted a plastic mesh in the back of the trap to provide a bait compartment. Occasionally, dead chicks and quails were also used as a bait. Trapped animals were allowed to feed on the bait to reduce capture stress (Crawshaw \& Quigley 1989). Drinking water and food for the bait were checked and replaced at least once a day. We recorded the amount of food eaten by live baits in a daily basis. We calculated bait death rates as the number of live baits dead divided by the total time effort done using that type of bait. We classified an event as a bait theft when a bait was removed from the trap with no animal captured inside.

\section{Handling and anesthesia}

After caught in the trap, a biologist or a veterinary evaluated general health, body condition and estimated body weight. A blowpipe and 3cc nylon darts (Telinject, Romerberg, Germany) were then prepared with an estimated $10 \mathrm{mg} / \mathrm{kg}$ dose of Tiletamine Hipocloride and Zolazepam Hipocloride association (Zoletil ${ }^{\mathrm{TM}}$, Virbac do Brasil, São Paulo, Brazil). One person would approach the trap to attract the animal's attention while another would use the blowpipe to anesthetize it. After intramuscular injection in the upper thigh area, the animal was observed from a distance until immobilized. When needed, supplemental doses were applied intramuscularly by hand injection. Once under anesthesia, ocelots were treated with an ophthalmic ointment, had their eyes covered, and were checked by a veterinarian for vital parameters. We implanted a subcutaneous microchip in all ocelots (Animal Tag, São Carlos-SP, Brazil) between the shoulder blades.

We recorded each animal's response to Zoletil and time of those responses. We defined cataleptic anesthesia as the interval (min) from Zoletil injection to first signs of ocelot's recovery. Incapacity time was defined as the interval from Zoletil injection until total recovery. Following immobilization, we weighed, measured, determined age class based on tooth wear and morphological measurements, and took blood and ectoparasite samples. Ocelots were aged as adults ( $>24$ months), subadults (12 to 24 months) and juveniles ( $<12$ months). We also recorded information on trap injuries, heart and respiratory rates (every $15 \mathrm{~min}$.), sex, and other parameters (Appendix A). During anesthesia, we recorded rectal temperature using a digital thermometer at 15 -min intervals. We recorded hypothermia (rectal temperature below $37.0^{\circ} \mathrm{C}$ ), hyperthermia (rectal temperature above $40.0^{\circ} \mathrm{C}$ ), dehydration, excessive salivation and muscle tremors during anesthesia. After first signs of anesthesia recovery, animals were put back into the trap and the door closed until total recovery and release by the biologist in charge. Capture and handling procedures were approved by the Ethics Committee on the Use of Animals in Research of 

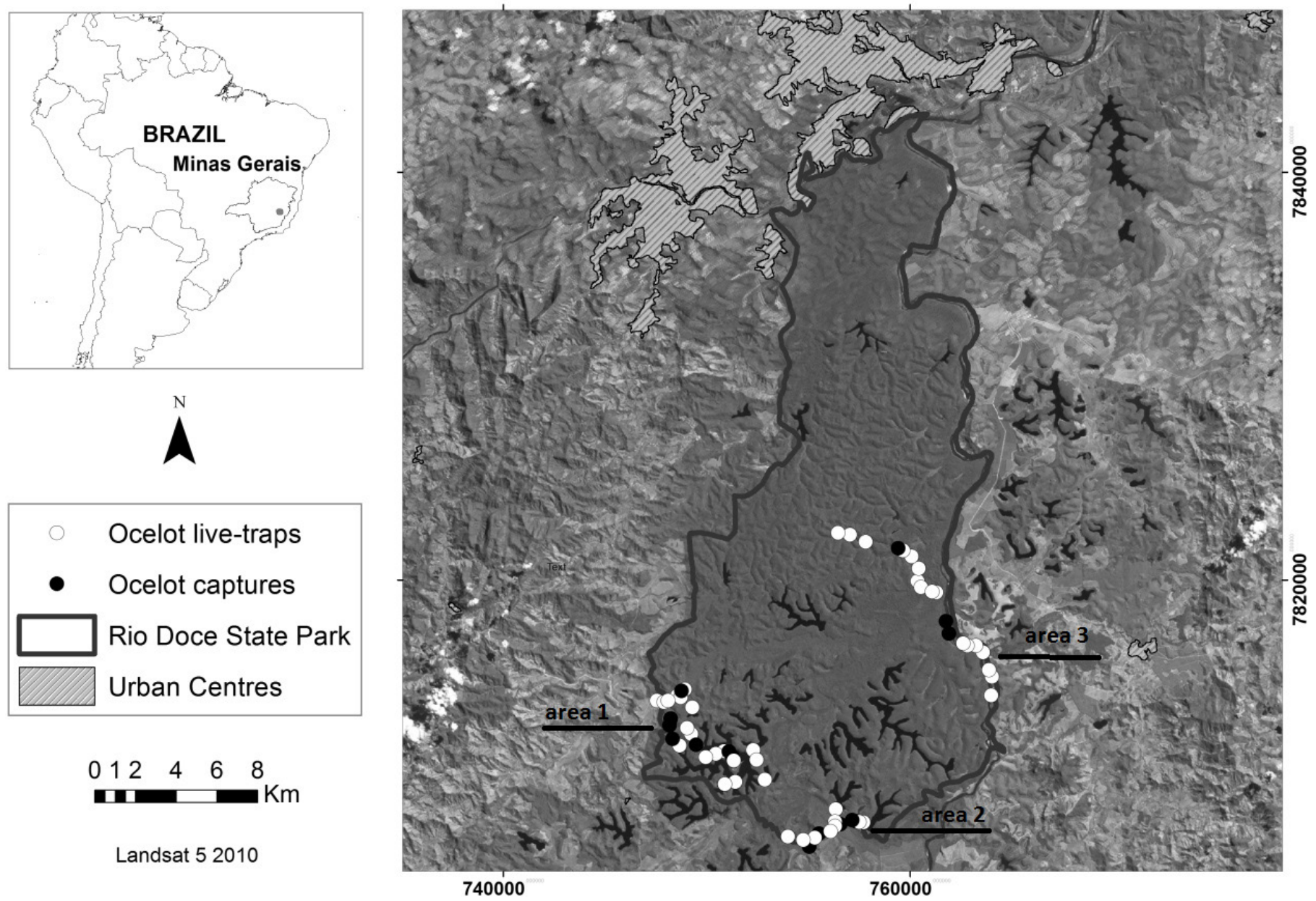

\section{$012 \quad 4 \quad 6 \quad 8$

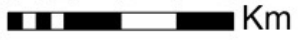

Landsat 52010

Figure 1. Map of Rio Doce State Park showing ocelot live-trap and capture sites in 2012 and 2013. Three different areas of RDSP were surveyed during this study using the following criteria: easy access, reports of park rangers about the presence of wild carnivores and distance away from cities.

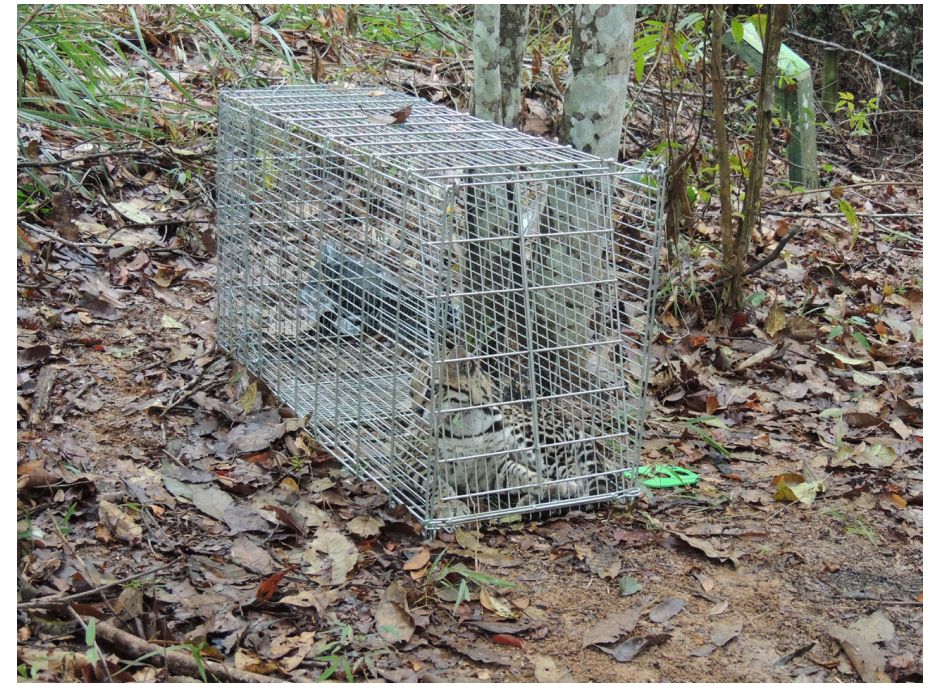

Figure 2. Cage trap utilized for ocelot trapping at Rio Doce State Park, Minas Gerais, Brazil, in 2012 and 2013.

Escola Superior de Agricultura Luiz de Queiroz (ESALQ) - University of São Paulo (USP), Sistema de Autorização e Informação em Biodiversidade (SISBio, permit 34284-1), Instituto Estadual de Florestas de Minas Gerais (IEF, permit UC053/12) and Ethics Committee on the Use of Animals in
Research of Universidade Federal de São João del Rei (UFSJ -003/20013, CEUA/UFSJ).

\section{Costs}

During field work, we kept receipts and took notes of all relevant expended money for accountability. Costs of vehicle and personnel time were calculated from market prices and scholarships values of experienced graduate students involved in the project. In addition, field assistants were provided by RDSP to help during captures and their daily cost was calculated based on current market prices for the Minas Gerais State in Brazil. All costs were calculated based on 2012 United States Dollars (US\$).

\section{Analysis}

Capture efficiency for our data and for available literature data (see Appendix B) was calculated based on the number of ocelot capture events per 1,000 trap-nights effort (Mowat et al. 1994). Bait success was measured by dividing the number of ocelot captures by the total trap-night effort of that specific bait. Each live bait cost was calculated by the sum of the bait and food costs divided by the total trap-night effort using that bait. We also evaluated the influence of environmental factors such as moonlight, average temperature and precipitation on capture success. To evaluate the effect of moonlight, data on moon phase, number of hours the moon was exposed and the fraction of moon illuminated were used to calculate a moonlight index. The index was calculated as the fraction of 
moon illuminated (\%) multiplied by the number of hours the moon was exposed and visible during each night of trapping. Data on moonlight phases was obtained from Time and Date AS (2014). Data on average temperature and precipitation were obtained from Instituto Nacional de Pesquisas Espaciais (INPE 2014) specifically for the year 2012 when all the first captures of adult ocelots were realized. We used logistic regression to evaluate the influence of moon phase, temperature, precipitation and moonlight index on ocelot capture success. A successful capture was scored 1 and an unsuccessful 0 . Moon phase was entered as a categorical variable scored 1 full, 2 half and 3 dark. Temperature and precipitation were entered as continuous variables. Capture selectivity was calculated based on ocelot capture events divided by the total captures (ocelots and non-targets) (modified from Fleming et al. 1998).

Injury rate, the proportion of injuries that might affect or even cause death of target and non-target individuals divided by total capture events (adapted from McBride-Jr \& McBride 2007, McCarthy et al. 2013), was divided into three categories: (i) Very minor injuries (very minor cuts, abrasions, claw damage, rubbing), (ii) Minor injuries (not likely to cause animal's death - i.e. superficial lacerations and abrasions), and (iii) Major injuries (likely to cause animal's death - i.e. deep lacerations, severe bleeding lesions; adapted from Mowat et al. 1994). We calculated injury rates for ocelots (injuries/total ocelot capture events) and for all captures (all injuries/all total captures).

We used Pearson correlations to examine relationships between body weight and dosage to cataleptic anesthesia, incapacity time, and minimum or maximum body temperature. We did not included induction time in our analysis. We used the Kolmogorov-Smirnov test to evaluate normality of data. Ocelot capture cost was calculated by the total cost of the project divided by the number of ocelot capture events (adapted from Austin et al 2004; Mowat et al. 1994).

\section{Results}

In 86 days of captures, we had 1,011 trap-night effort, 68 capture events ( $6.7 \%$ success) and 24 bait thefts ( $2.4 \%$ bait loss). We detected thefts by examining hairs left inside the trap. Capture events were composed of ocelots $(22 \%, \mathrm{n}=15)$ and non-target species $(78 \%, n=53)$ such as tayra (Eira Barbara) and jaguarundi (Puma yagouaroundi) $(n=2)$, big-eared opossums $(n=26)$ and other mammals, birds and reptiles $(\mathrm{n}=25)$ (Table 1). We captured 10 individual ocelots being nine adults ( 5 males, 4 females) and one subadult female in 15 capture events ( 6 males, 9 females events), corresponding to 5.7 days with 15 trap-nights per ocelot capture. Capture efficiency was 14.8 ocelots/1,000 trap-nights effort. Mean values of body mass for male ocelots $(11.3 \pm 2.52$ S.D. $)$ did not differ from mean values for females $(9.3 \pm 1.07)(d f=7, t=1.452, P=0.19)$. Ocelot capture selectivity was $22 \%$. Regarding the environmental factors that could have affected capture success, logistic regression analysis showed that moon phase, moonlight index, temperature and precipitation were not significant predictors of capture success of ocelots during 2012 (Table 2).

Among the baits tested, only the two live baits were successful in capturing ocelots. We captured six ocelots in 323 trap-nights using live chicks (18.5 ocelots/1,000 trap-nights) and nine ocelots in 562 trap-nights using live quails (16.0 ocelots/1,000 trap-nights). Other baits comprised 126 trap-night effort (Table 3). The main difficulties with bait use were thefts, especially from black capuchins, ants (once ants discovered the trap, it was moved away) and trap-happy opossums (after the second capture of the same individual in the same trap we would move the trap). Quails consumed 206 gr of food/quail and chicks consumed 455 gr of food/chick. Death rates for quails and chicks were $0.53 \%$ and $2.16 \%$ per day respectively.

In general, animals that fought to escape the trap targeted the door, back, or lateral walls near door and the pedal. In the case of ocelots, only three animals presented very minor injuries, which represents $20 \%$ of all ocelots captured and $4.4 \%$ when all captures are considered. Two ocelots presented minor gum lesions and one presented a superficial abrasion on the nose. Another ocelot had an uncomplicated crown fracture on its cheek tooth that could not be proven to be due to trapping.

Considering all captures, injuries in other species represented only $3.0 \%(n=2)$. Other injured animals were a yagouaroundi and a tayra. The yagouaroundi had abrasive lesions and swelling on the face (minor injury; Figure 3a) as a result of the animal jumping and beating its head against the trap. This might also have been a consequence of too much time inside the trap, since it is a diurnal species and most traps were checked only once a day between 6:00 to 8:00 am. The tayra had a deep punctual lesion in the gum resulting in severe bleeding, which, after chemical immobilization, was reversed by lesion compression for some minutes (major injury). The tayra's injury was a result of the animal trying to chew its way out of the trap after noticing the presence of people near the trap and having success on breaking the rods of lateral wall near the door (Figure 3b).

Ocelots were considered calm during trap approach in eight capture events and alert in the other seven. They were considered healthy in 11 capture events and under mild disease associated with weight loss in another four (see Widmer et al. 2016).

Table 1. Capture events per group and respective proportion to total capture events at Rio Doce State Park, Minas Gerais, Brazil, 2012 and 2013.

\begin{tabular}{|c|c|c|c|c|}
\hline \multicolumn{3}{|c|}{ Captured animal } & \multirow{2}{*}{ Capture events } & \multirow{2}{*}{ Proportion (\%) } \\
\hline Order & Family & Species & & \\
\hline \multirow[t]{4}{*}{ Carnivora } & Felidae & Ocelot (Leopardus pardalis) & 15 & 22.0 \\
\hline & Felidae & Yagouaroundi (Puma yagouaround) & 1 & 1.5 \\
\hline & Mustelidae & Tayra (Eira barbara) & 1 & 1.5 \\
\hline & Canidae & Domestic dog (Canis familiaris) & 2 & 2.9 \\
\hline \multirow[t]{2}{*}{ Didelphimorphia } & Didelphidae & Big-eared opossum (Didelphis aurita) & 26 & 38.2 \\
\hline & & Brown four-eyed opossum (Metachirus nudicaudatus) & 3 & 4.4 \\
\hline Primates & Cebidae & Black capuchin monkey (Sapajus nigritus) & 1 & 1.5 \\
\hline Lagomorpha & Leporidae & Tapeti (Sylvilagus brasiliensis) & 1 & 1.5 \\
\hline Cingulata & Dasypodidae & Nine-banded armadillo (Dasypus novemcinctus) & 1 & 1.5 \\
\hline \multirow[t]{2}{*}{ Accipitriformes } & Accipitridae & Roadside hawk (Rupornis magnirostris) & 6 & 8.8 \\
\hline & & White hawk (Leucopternis sp.) & 1 & 1.5 \\
\hline Falconiformes & Falconidae & Collared forest falcon (Micrastur semitorquatus) & 3 & 4.4 \\
\hline Cariamiformes & Cariamidae & Red legged siriema (Cariama cristata) & 1 & 1.5 \\
\hline Squamata & Teiidae & Tupinambis (Tupinambis sp.) & 6 & 8.8 \\
\hline Total & & & 68 & 100.0 \\
\hline
\end{tabular}


Table 2. Logistic regression model testing the effects of environmental factors on ocelot capture success at Rio Doce State Park, 2012.

\begin{tabular}{lccccc}
\hline \multicolumn{1}{c}{ Variable } & $\boldsymbol{B}$ & $\boldsymbol{S} . \boldsymbol{E}$. & Wald & $\boldsymbol{d f}$ & $\boldsymbol{P}$ \\
\hline $\begin{array}{l}\text { Moon phase } \\
\text { (categorical variable) }\end{array}$ & -0.927 & 0.795 & 1.358 & 1 & 0.244 \\
$\begin{array}{l}\text { Index } \\
\text { (continuous variable) }\end{array}$ & -0.251 & 0.211 & 1.417 & 1 & 0.234 \\
$\begin{array}{l}\text { Temperature } \\
\text { (continuous variable) }\end{array}$ & -0.226 & 0.134 & 2.864 & 1 & 0.091 \\
$\begin{array}{l}\text { Precipitation } \\
\text { (continuous variable) }\end{array}$ & 0.022 & 0.050 & 0.202 & 1 & 0.653 \\
\hline
\end{tabular}

Hand injection was tried in calm animals, but was unsuccessful since the animals move and turn around too fast. Data from two of the 15 capture events were excluded because we could not be sure of the dosage of first injection due to dart problems. Mean initial dose was $10.4 \mathrm{mg} / \mathrm{kg}$ ( \pm 1.63 S.D., range $=7.74$ to 14.28 ), which resulted in 10 cataleptic anesthesia, one sedation, and two light sedations. The three sedations required a supplemental dose of anesthetic. Induction time for animals that reached cataleptic anesthesia with first dose varied between three to 10 minutes. Data for doses and effects are shown in Table 4. We recorded hypothermia, hyperthermia, dehydration, excessive salivation and muscle tremors during anesthesia. Besides excessive salivation, one ocelot presented muscle tremors during

Table 3. Bait success and bait losses at Rio Doce State Park 2012 and 2013. The success of each bait was measured dividing the number of captures by the total trapnight effort of that specific bait.

\begin{tabular}{|c|c|c|c|c|c|c|}
\hline \multicolumn{7}{|c|}{ Bait success (number of captures or thefts) } \\
\hline $\begin{array}{l}\text { Species captured (effort in } \\
\text { trap-nights) }\end{array}$ & $\begin{array}{c}\text { Sardine }+ \text { Bacon } \\
\text { (36) }\end{array}$ & $\begin{array}{l}\text { Bacon } \\
(10)\end{array}$ & $\begin{array}{c}\text { Roast chicken } \\
\text { (47) }\end{array}$ & $\begin{array}{l}\text { Live chicks } \\
\quad(323)\end{array}$ & $\begin{array}{l}\text { Dead chick } \\
\quad(25)\end{array}$ & $\begin{array}{l}\text { Live quail } \\
562\end{array}$ \\
\hline Ocelots & 0 & 0 & 0 & $1.85(6)$ & 0 & $1.6(9)$ \\
\hline Other carnivores & 0 & 0 & 0 & $0.31(1)^{\mathrm{Y}}$ & $4.0(1)^{\mathrm{T}}$ & - \\
\hline Domestic dogs & 0 & $10.0(1)$ & 0 & 0 & 0 & $0.17(1)$ \\
\hline Big-eared opossums & 0 & 0 & $4.25(2)$ & $2.47(8)$ & $8.0(2)$ & $2.49(14)$ \\
\hline Hawks (4 spp.) & 0 & 0 & 0 & $1.85(6)$ & $4.0(1)$ & $0.53(3)$ \\
\hline Tupinambis & 0 & 0 & 0 & 0 & 0 & $1.06(6)$ \\
\hline Others & 0 & $10.0(1)$ & $4.25(2)$ & 0 & $4.0(1)$ & $0.53(3)$ \\
\hline Total captures & 0 & $20.0(2)$ & $8.51(4)$ & $6.5(21)$ & $20.0(5)$ & $6.4(36)$ \\
\hline Thefts & $5.5(2)$ & 0 & $4.25(2)$ & $3.09(10)$ & $4.0(1)$ & $1.6(9)$ \\
\hline
\end{tabular}

${ }^{\mathrm{Y}}$ Yagouaroundi (Puma yagouaroundi). ${ }^{\mathrm{T}}$ Tayra (Eira Barbara)
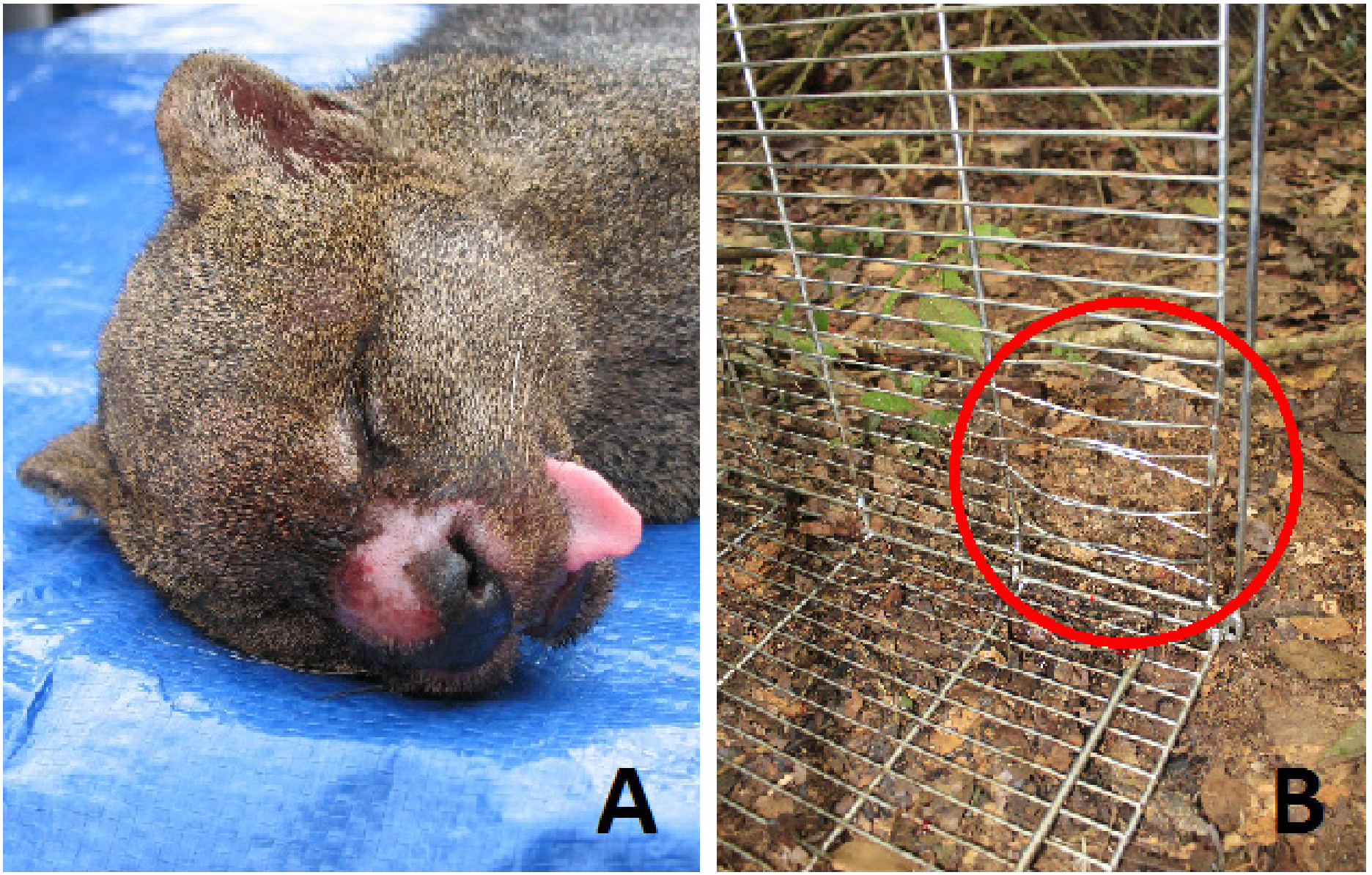

Figure 3. A) Yagouroundi (Puma yagouaroundi) presenting abrasive lesions and swelling of face. B) Bent rods near trap door that were chewed by a tayra (Eira barbara) at Rio Doce State Park during 2012 capture campaign. 
Widmer, C.E. et al.

Table 4. Zoletil ${ }^{\mathrm{TM}}$ doses and effects on 13 wild ocelots captured at Rio Doce State Park, Minas Gerais, Brazil, 2012 and 2013.

\begin{tabular}{|c|c|c|c|}
\hline & Variables measured & Mean ( \pm SD) & Range \\
\hline \multirow{6}{*}{$\begin{array}{l}\text { Animals that received single dose } \\
(\mathrm{n}=10)\end{array}$} & Body weight (kg) & $10.08(2.30)$ & $7.0-15.5$ \\
\hline & Zoletil Tм dose (mg/kg) & $10.30(1.88)$ & $7.74-14.28$ \\
\hline & Cataleptic anesthesia (min) & $136.0(57.43)$ & $50-210$ \\
\hline & Incapacity $(\min ) *$ & $257.2(59.16)$ & $170-350$ \\
\hline & Minimum rectal temperature $\left({ }^{\circ} \mathrm{C}\right)$ & $36.98(0.85)$ & $36.1-38.9$ \\
\hline & Maximum rectal temperature $\left({ }^{\circ} \mathrm{C}\right)$ & $38.96(0.77)$ & $38.1-40.5$ \\
\hline \multirow{8}{*}{$\begin{array}{l}\text { Animals that received supplement } \\
\text { dose }(n=3)\end{array}$} & Body weight (kg) & 9.3 & $6.8-11.0$ \\
\hline & 1rst Zoletil тм dose (mg/kg) & 10.4 & $10.0-10.9$ \\
\hline & 2nd Zoletil TM dose (mg/kg) & 2.9 & $1.0-5.1$ \\
\hline & Interval between injections (min) & 16.6 & $12-24$ \\
\hline & Cataleptic anesthesia $(\min )^{\mathrm{a}}$ & 28.0 & $25-31$ \\
\hline & Incapacity $(\min )^{\mathrm{a}}$ & 156.6 & $90-220$ \\
\hline & Minimum rectal temperature ${ }^{\mathrm{b}}\left({ }^{\circ} \mathrm{C}\right)$ & 37.5 & $37.2-37.9$ \\
\hline & Maximum rectal temperature ${ }^{\mathrm{b}}\left({ }^{\circ} \mathrm{C}\right)$ & 38.8 & $38.1-39.5$ \\
\hline
\end{tabular}

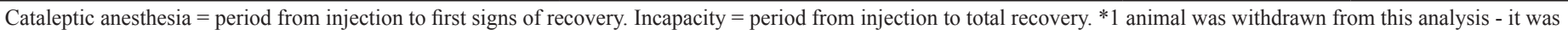
released earlier because it was fighting against the trap. ${ }^{a}$ time after second injection. ${ }^{\mathrm{b}}$ data from one animal was missing

Table 5. Anesthesia complications, their frequencies, and field treatments of ocelots captured at Rio Doce State Park, Minas Gerais, Brazil, 2012 and 2013.

\begin{tabular}{|c|c|c|}
\hline Complication & Frequency & In field treatment \\
\hline Hypothermia - (rectal temperature below $\left.37.0^{\circ} \mathrm{C}\right)$ & 5 & Paw bandage, cotton blanket, emergency blanket, car's hot air \\
\hline Hyperthermia - (rectal temperature above $40.0^{\circ} \mathrm{C}$ ) & 4 & 3 lowed spontaneously during anesthesia, 1 was cooled with water in paws and flank \\
\hline Dehydration - (mild loss of cutaneous elasticity) & 4 & Subcutaneous saline solution (30 to $60 \mathrm{ml} /$ animal) \\
\hline Excessive salivation & 3 & $0.01 \mathrm{mg} / \mathrm{kg}$ subcutaneous atropine sulfate \\
\hline Muscle tremors & 1 & Avoid sound stimulus \\
\hline
\end{tabular}

Table 6. Total costs of 1,011 trap-night effort at Rio Doce State Park, 2012 and 2013, in 86 days.

\begin{tabular}{lc}
\hline \multicolumn{1}{c}{ Item (quantity) } & $\begin{array}{c}\text { Approximate cost } \\
\text { (2012 US\$) }\end{array}$ \\
\hline Vehicle & $50,000.00$ \\
Experienced Field Veterinarian & $12,000.00$ \\
Experienced Field Biologist & $10,000.00$ \\
Field Assistant & $1,000.00$ \\
Vehicle maintenance (2) & $3,500.00$ \\
Tomahawk traps (15) & $2,500.00$ \\
Microchip kit (1) & 700.00 \\
Trap extras (wires, canvas, etc) - & 100.00 \\
Veterinary items (anesthetics, stethoscope, & $1,300.00$ \\
medications, etc) & \\
Handling equipment (scales, table, etc) & 800.00 \\
Daily wage - team maintenance & $1,500.00$ \\
Fuel (1800lts of Diesel) & $2,000.00$ \\
Personal protective equipment & 100.00 \\
Waterers (26) & 36.00 \\
Feeders (46) & 80.00 \\
Chick food (35kg) & 25.90 \\
Quail food (15kg) & 10.40 \\
Chicks (77) & 83.70 \\
Quails (73) & 114.30 \\
Total & $85,850.30$ \\
\hline
\end{tabular}

recovery when under sound stimulus. All hyperthermic ocelots were alert during trap approach. The main anesthesia complications and applied treatments are shown in Table 5. We found no significant relationship between body weight and cataleptic anesthesia $(r=-0.485, P=0.186)$, incapacity time $(r=0.052, P=0.903)$, minimum temperature $(r=-0.087$,
$P=0.825)$, and maximum temperature $(r=-0.438, P=0.239)$. Similarly, the dosage of Zoletil ${ }^{\mathrm{TM}}$ was not correlated to cataleptic anesthesia $(r=0.384$, $P=0.308)$, incapacity time $(r=0.083, P=0.845)$, minimum temperature $(r=-0.171, P=0.660)$ nor maximum temperature $(r=0.130, P=0.739)$.

The cost of using quails was US $\$ 0.26 /$ trap-night while chicks cost was US\$0.39/trap-night. Calculated cost for each ocelot capture was US\$ $5,723.35$ and the average for each of the 8 periods of captures was US\$ $11,106.29$. General costs of 8 periods of captures are shown in Table 6 .

\section{Discussion}

Previous reports in the peer-reviewed literature lack detail regarding ocelot capture and handling methods (see Appendix B). Many of these publications do not mention bait used, just a few report trap effort and only one reports trap-related injuries (Emmons 1988). Although some of authors mention anesthesia protocols, just the papers on anesthesiology report responses and side-effects (Beltran \& Tewes 1995; Shindle \& Tewes 2000). We found only one peer-reviewed literature reporting the costs of capturing non-target species (Newsome et al. 1983) and none specifically about costs of capturing ocelots.

Our capture efficiency using box-traps (14.84 ocelots/1,000 trap-nights) was higher than that reported for ocelots in forested areas of Belize, in the Chaco of Bolivia, and in the Cerrado of Brazil (Fiorello et al. 2006; Dillon \& Kelly 2008; Rocha et al. 2013) but lower than reported from forests of Venezuela (Ludlow \& Sunquist 1987). We found the model of traps used advantageous as they could be moved to different sites inside study area, contrary to what has been previously reported for box-traps (Mowat et al. 1994). Moreover box-traps were especially useful to house ocelots during anesthetic recovery (Mowat et al. 1994). We captured felids exclusively with live-baits (similar to Michalski et al. 2007), although there are reports of occasional ocelots captured using dead baits (i.e. Rocha et al. 
2013). Furthermore, our ocelot capture efficiency would be even higher if calculated considering only live-baits effort (17 ocelots/1,000 trap-nights). Among the baits, quails were cheaper, cleaner to handle, died less often than chicks and could be used indefinitely as baits, contrary to chicks that in 30-60 days would grow too large for the bait compartment.

We found no relationships between capture success and environmental factors probably because of our small sample size of ocelots captured. In addition, we would need to increase our capture effort during more years/seasons in order to increase the chances of finding any possible significant relationship.

Our selectivity of live-trapping ocelots $(22.06 \%)$ was similar to the selectivity for box-trapping felids (22.58\%) of the only available published data from Brazil (Michalski et al. 2007). This rate can be considered low, as expected for box-trapping (McCarthy et al. 2013), when compared to other methods such as leg hold traps for pumas $(70.13 \%$, calculated from Logan et al. 1999). However, box-traps are considerably safer and cause less injuries to both target and non-target species (i.e. Mowat et al. 1994).

We consider our injury rate for ocelots acceptable. Even it was not possible to compare our result with other ocelot box-trapping data due to the lack of this information reported, other similar felid species such as the Canadian lynx had 32\% minor injuries (Mowat et al. 1994). To avoid non-target species injuries, the method we used needs to be improved, once their capture appears inevitable.

Our results were contrary to the expectations for tropical environments, because hypothermia was the main anesthesia side effect (McCarthy et al. 2013). Our dose of $10 \mathrm{mg} / \mathrm{kg}$ of the association of tiletamine and zolazepam (Rabinowitz 1990) when compared to the literature's $5 \mathrm{mg} / \mathrm{kg}$ dose (Shindle \& Tewes 2000) resulted in a longer period of cataleptic anesthesia but surprisingly a very similar time of motor incapacity. Despite the small number of animals captured, the great variation of response using similar doses for all ocelots supports the hypothesis of individual response to anesthetics being the main factor influencing response to the association of tiletamine and zolazepam (Shindle \& Tewes 2000).

Besides considering efficiency, selectivity and injury rate for capture success, we believe evaluating capture costs is also important when selecting live-trapping methods for research (Austin et al. 2004). When costs of capturing carnivores are mentioned, they are restricted to capture devices (i.e. Mowat et al. 1994; Austin et al. 2004), and do not consider other logistical costs which may be influenced by the capture method itself and the duration of the project.

In order to improve the trap's safety for other species we suggest a reduction to less than $10 \mathrm{~cm}$ in the spaces between the 4 vertical rods near the door and back of the trap, and to increase the number of horizontal rods on the door to reduce to $5 \mathrm{~cm}$ the distance between the 6 lower rods, therefore preventing animals chewing on the rods. We also suggest shutting the traps during the day or performing more than one check per day (i.e. by the use of trap-transmitters). Concerning the use of live baits, we recommend choosing locally raised animals, evaluating the need of eventual preventive medical treatment/tests on live baits to avoid disease transfer to the study area and that sick birds are promptly replaced.

Because of the great variation in the response to the anesthetics and the long recovery period and adverse effects on some individuals, we recommend that other anesthesia protocols be tested for free-ranging ocelots. Based on the results presented here and authors' previous experiences, we highlight the importance of having anesthesia protocols for all non-target species that might be captured and also to promptly release or anesthetize mustelids as soon as they are found trapped in order to avoid possible injuries.

Regarding selectivity, it would be especially useful to develop strategies to avoid the capture of opossums, for instance, reinforcing the mesh wire between the bait and the trapped animal and using a less sensitive treadle, since they represent the majority of capture events. Because live-trapping and immobilizing carnivores is expensive and requires an experienced team (McCarthy et al. 2013), we advocate that substantial and long term funding would decrease the cost of each capture, since most expensive items (for instance vehicle) could be used for a longer period without a significant increase in the total costs and, furthermore, would allow the persistence of trained personnel and the conduction of long-term health and ecological research projects targeting threatened species.

Considering the inherent risks of live-trapping, the endangered status of species that might get trapped and the insufficiency of data, we recommend

Appendix A. Parameters evaluated from captured ocelots captured at Rio Doce State Park, Minas Gerais, Brazil, 2012 and 2013.

\begin{tabular}{|c|c|c|c|c|c|}
\hline Behaviour & General Health & Body condition & Anesthesia & Hydration status & $\begin{array}{c}\text { Anesthesia } \\
\text { complications }\end{array}$ \\
\hline Calm & Normal & Normal & No effect & Normal & None \\
\hline Alert & Mild disease & Underweight & Mild sedation & Mild dehydration & Excessive salivation \\
\hline Agressive & Severe disease & Cachectic & Sedation & Moderate dehydration & Hypothermia \\
\hline \multirow[t]{4}{*}{ Apprehensive } & High anesthetic risk & Overweight & Cataleptic anesthesia & Severe dehydration & Hyperthermia \\
\hline & & & Overdose & & Respiratory alterations \\
\hline & & & & & Cardiac alterations \\
\hline & & & & & Other \\
\hline
\end{tabular}

Appendix B. Data on ocelot capture method from peer-reviewed reports.

\begin{tabular}{|c|c|c|c|c|c|c|c|c|c|c|c|}
\hline Country & $\begin{array}{l}\text { Captured } \\
\text { ocelots } \\
\text { (capture } \\
\text { events) } \\
\end{array}$ & Study objective & Trap used & $\begin{array}{l}\text { Bait } \\
\text { used }\end{array}$ & $\begin{array}{l}\text { Duration } \\
\text { (trap-night } \\
\text { effort) }\end{array}$ & $\begin{array}{l}\text { Anesthesia protocol } \\
\text { (dose) }\end{array}$ & $\begin{array}{l}\text { Capture } \\
\text { efficiency }^{1}\end{array}$ & Injuries & $\begin{array}{c}\text { Non- } \\
\text { target } \\
\text { captures }\end{array}$ & Costs & Reference \\
\hline Belize & $7(13)$ & Ecology & Box-trap & $\begin{array}{l}\text { Live } \\
\text { chicken } \\
\text { and lures }\end{array}$ & $\begin{array}{l}1 \text { year } \\
(1040)\end{array}$ & $\begin{array}{l}\text { Tiletamine-zolazepam- } \\
\text { xylazine-butorphanol } \\
\text { (25:15:1) and ketamine } \\
\text { (supplementation) }\end{array}$ & 12.5 & - & - & - & $\begin{array}{l}\text { (Dillon and } \\
\text { Kelly 2008) }\end{array}$ \\
\hline Bolivia & 10 & Epidemiology & Box-trap & - & $\begin{array}{l}2 \text { years } \\
(1,514)\end{array}$ & $\begin{array}{l}\text { Ketamine }(5.8 \mathrm{mg} / \mathrm{Kg})- \\
\text { medetomidine } \\
(0.06 \mathrm{mg} / \mathrm{Kg})\end{array}$ & 6.60 & - & - & - & $\begin{array}{l}\text { (Fiorello et al. } \\
\text { 2006) }\end{array}$ \\
\hline
\end{tabular}

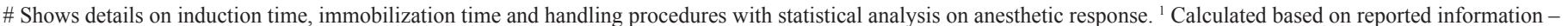
ocelot capture events / 1,000 trap-nights effort. ${ }^{2}$ Data from animals on the blood collection group. - Data not available. 
Appendix B. Continued...

\begin{tabular}{|c|c|c|c|c|c|c|c|c|c|c|c|}
\hline Country & $\begin{array}{l}\text { Captured } \\
\text { ocelots } \\
\text { (capture } \\
\text { events) } \\
\end{array}$ & Study objective & Trap used & $\begin{array}{l}\text { Bait } \\
\text { used }\end{array}$ & $\begin{array}{l}\text { Duration } \\
\text { (trap-night } \\
\text { effort) }\end{array}$ & $\begin{array}{l}\text { Anesthesia protocol } \\
\text { (dose) }\end{array}$ & $\begin{array}{l}\text { Capture } \\
\text { efficiency }^{1}\end{array}$ & Injuries & $\begin{array}{c}\text { Non- } \\
\text { target } \\
\text { captures }\end{array}$ & Costs & Reference \\
\hline Brazil & $3 / 1$ & Ecology & $\begin{array}{l}\text { Box-trap } \\
\text { and Leg } \\
\text { hold trap/ } \\
\text { Trained } \\
\text { dogs } \\
\end{array}$ & $\begin{array}{l}\text { Live } \\
\text { chicken }\end{array}$ & - & $\begin{array}{l}\text { Tiletamine-zolazepam } \\
(7 \mathrm{mg} / \mathrm{Kg}) / \mathrm{Ketamine}- \\
\text { xilazine }(3.3 \mathrm{mg} / \\
\mathrm{kg}: 0.3 \mathrm{mg} / \mathrm{Kg})\end{array}$ & - & - & - & - & $\begin{array}{l}\text { (Crawshaw } \\
\text { and Quigley } \\
1989)\end{array}$ \\
\hline Brazil & 6 & $\begin{array}{c}\text { Ecology/ } \\
\text { Epidemiology }\end{array}$ & - & - & 6 years & - & - & - & - & - & $\begin{array}{l}\text { (Labruna et al. } \\
\text { 2005) }\end{array}$ \\
\hline Brazil & 1 & $\begin{array}{c}\text { Ecology/ } \\
\text { Epidemiology }\end{array}$ & Box trap & - & 6 years & Tiletamine-zolazepam & - & - & - & - & $\begin{array}{l}\text { (Filoni et al. } \\
2006 \text { ) }\end{array}$ \\
\hline Brazil & 2 & Epidemiology & $\begin{array}{l}\text { Box trap / } \\
\text { Trained } \\
\text { dogs }\end{array}$ & - & 6 years & Tiletamine-zolazepam & - & - & - & - & $\begin{array}{l}\text { (Nava et al. } \\
\text { 2008) }\end{array}$ \\
\hline Brazil & 1 & Epidemiology & Box trap & $\begin{array}{l}\text { Sardine } \\
\text { and } \\
\text { boiled } \\
\text { chicken }\end{array}$ & $\begin{array}{l}4 \text { years } \\
(3,819)\end{array}$ & $\begin{array}{l}\text { Tiletamine-zolazepam } \\
(8.3 \mathrm{mg} / \mathrm{Kg})\end{array}$ & 0.26 & - & - & - & $\begin{array}{l}\text { (Rocha et al. } \\
\text { 2009) }\end{array}$ \\
\hline Brazil & 10 & $\begin{array}{c}\text { Ecology/ } \\
\text { Epidemiology }\end{array}$ & - & - & 6 years & - & - & - & - & - & $\begin{array}{l}\text { (Jorge et al. } \\
2010)\end{array}$ \\
\hline Mexico & $17(21)$ & Epidemiology & Box-trap & - & 8 years & Ketamine-xilazine & - & - & - & - & $\begin{array}{l}\text { (Rendón- } \\
\text { Franco et al. } \\
\text { 2012) } \\
\end{array}$ \\
\hline Panama & 12 & Epidemiology & Box-trap & - & 3 years & $\begin{array}{l}\text { Tiletamine-Zolazepam/ } \\
\text { Ketamine-xilazine }\end{array}$ & - & - & - & - & $\begin{array}{l}\text { (Franklin et al. } \\
\text { 2008) }\end{array}$ \\
\hline Panama & 3 & Ecology & Box-trap & $\begin{array}{l}\text { Live } \\
\text { chicken }\end{array}$ & & Ketamine-xylazine & & - & - & - & $\begin{array}{l}\text { (Mares et al. } \\
\text { 2008) }\end{array}$ \\
\hline Peru & $9(8 / 10)$ & $\begin{array}{l}\text { Ecology, } \\
\text { Behaviour }\end{array}$ & $\begin{array}{l}\text { Box-trap / } \\
\text { Leg snares }\end{array}$ & $\begin{array}{l}\text { Live } \\
\text { chicken }\end{array}$ & - & $\begin{array}{l}\text { Ketamine- } \\
\text { chlorpromazine }\end{array}$ & - & $\begin{array}{l}\text { Swollen } \\
\text { foot from } \\
\text { snare }\end{array}$ & - & - & $\begin{array}{l}\text { (Emmons } \\
1988)\end{array}$ \\
\hline Venezuela & $12 / 1$ & Ecology & Box-trap & $\begin{array}{l}\text { Live } \\
\text { chicken / } \\
\text { Unbaited } \\
\end{array}$ & $\begin{array}{l}2 \text { years } \\
(334 / 30)\end{array}$ & Ketamine $(23-28 \mathrm{mg} / \mathrm{Kg})$ & $\begin{array}{l}35.93 / \\
33.33\end{array}$ & - & - & - & $\begin{array}{l}\text { (Ludlow and } \\
\text { Sunquist } \\
1987 \text { ) } \\
\end{array}$ \\
\hline USA & 10 & Anesthesiology & Box-trap & $\begin{array}{l}\text { Live } \\
\text { chicken }\end{array}$ & 8 months & $\begin{array}{l}\text { Ketamine-xilazine } \\
(14.1 \mathrm{mg} / \mathrm{kg}: 1.1 \mathrm{mg} / \mathrm{kg})^{\#}\end{array}$ & - & - & - & - & $\begin{array}{l}\text { (Beltran and } \\
\text { Tewes 1995) }\end{array}$ \\
\hline $\mathrm{USA}^{2}$ & $20(25)$ & Toxicology & Box-trap & $\begin{array}{l}\text { Live } \\
\text { chicken }\end{array}$ & 3,5 years & $\begin{array}{l}\text { Ketamine-acepromazine } \\
(19 \mathrm{mg} / \mathrm{Kg} / 0,19 \mathrm{mg} / \mathrm{Kg})\end{array}$ & - & - & - & - & $\begin{array}{l}\text { (Mora et al. } \\
2000 \text { ) }\end{array}$ \\
\hline USA & $11(13)$ & Anesthesiology & Box-trap & $\begin{array}{l}\text { Live } \\
\text { chicken }\end{array}$ & 1 year & $\begin{array}{l}\text { Tiletamine-zolazepam } \\
(5 \mathrm{mg} / \mathrm{Kg})^{\#}\end{array}$ & - & - & - & - & $\begin{array}{l}\text { (Shindle and } \\
\text { Tewes 2000) }\end{array}$ \\
\hline USA & 33 & Ecology & Box-trap & $\begin{array}{l}\text { Live } \\
\text { chicken }\end{array}$ & 8 years & $\begin{array}{l}\text { Ketamine-xilazine } \\
(14.1 \mathrm{mg} / \mathrm{kg}: 1.1 \mathrm{mg} / \mathrm{kg})\end{array}$ & - & - & - & - & $\begin{array}{l}\text { (Harveson et al. } \\
\text { 2004) }\end{array}$ \\
\hline USA & 80 & $\begin{array}{l}\text { Ecology } \\
\text { (survival and } \\
\text { sources of } \\
\text { mortality) } \\
\end{array}$ & Box-traps & $\begin{array}{l}\text { Live } \\
\text { chicken }\end{array}$ & 19 years & $\begin{array}{l}\text { Ketamine-acepromazine } \\
(9: 1 \mathrm{ratio}, 20 \mathrm{mg} / \mathrm{Kg})\end{array}$ & - & - & - & - & $\begin{array}{l}\text { (Haines et al. } \\
\text { 2005) }\end{array}$ \\
\hline USA & 15 & Theriogenology & Box-trap & $\begin{array}{l}\text { Live } \\
\text { chicken }\end{array}$ & 15 years & $\begin{array}{l}\text { Ketamine-acepromazine } \\
(9: 1,20 \mathrm{mg} / \mathrm{kg})\end{array}$ & - & - & - & - & $\begin{array}{l}\text { (Laack et al. } \\
2005 \text { ) }\end{array}$ \\
\hline USA & 1 & Ecology & Box-trap & - & - & $\begin{array}{l}\text { Tiletamine-Zolazepam } \\
(10-15 \mathrm{mg} / \mathrm{Kg})\end{array}$ & - & - & - & - & $\begin{array}{l}\text { (Haines et al. } \\
\text { 2006) }\end{array}$ \\
\hline
\end{tabular}

\# Shows details on induction time, immobilization time and handling procedures with statistical analysis on anesthetic response. ${ }^{1}$ Calculated based on reported information ocelot capture events / 1,000 trap-nights effort. ${ }^{2}$ Data from animals on the blood collection group. - Data not available.

the implementation of studies designed to test and compare different methods of capturing neotropical carnivores. To enable comparisons of studies from different research groups and from different study areas, allowing a deliberate choice of the best method, we suggest capture methods should be selected and implemented aiming the following criteria: (i) high capture efficiency; (ii) high selectivity; (iii) low injury rate; (iv) high immobilization suitability (safe for the animal, suitable to time to procedures, fast recovery and predictable effects, adapted from Austin et al. 2004, Mowat et al. 1994); and (v) low costs.

\section{Acknowledgments}

This work was partially supported by a $\mathrm{PhD}$ grant from Fundação de Amparo à Pesquisa do Estado de São Paulo (FAPESP (2010/00907-8) and Hidroex-Universidade Federal de Viçosa. We thank Programa de Pesquisa Ecológica de Longa Duração (PELD/CNPQ) Rio Doce and Instituto Estadual de Florestas (IEF-MG) - RSPD for logistical support, and volunteer biologists and undergraduate students that helped in data collection. 


\section{References}

AUSTIN, J., CHAMBERLAIN, M., LEOPOLD, B. \& BURGER-JR., L. 2004. An evaluation of EGGTM and wire cage traps for capturing raccoons. Wildlife Society Bulletin 32:351-356.

BAREA-AZCÓN, J. M., VIRGÓS, E., BALLESTEROS-DUPERÓN, E., MOLEÓN, M. \& CHIROSA, M. 2006. Surveying carnivores at large spatial scales: a comparison of four broad-applied methods. Biodivers. Conserv. 16:1213-1230.

BELTRAN, J. \& TEWES, M. 1995. Immobilization of ocelots and bobcats with ketamine hydrochloride and xylazine hydrochloride. Journal of Wildlife Diseases 31:43-48.

CITES - CONVENTION ON INTERNATIONAL TRADE IN ENDANGERED SPECIES OF WILD FAUNA AND FLORA. 2013. Appendix I. http://www. cites.org/sites/default/files/eng/app/2013/E-Appendices-2013-06-12.pdf. Accessed 02 July 2014.

CRAWSHAW, P. G. \& QUIGLEY, H. B. 1989. Notes on ocelot movement and activity in the Pantanal region, Brazil. Biotropica 21:377-379.

DA SILVA JÚNIOR, W. M., MELO, F. R., MOREIRA, L. S., BARBOSA, E. F. \& MEIRA-NETO, J. A. A. 2009. Structure of Brazilian Atlantic forests with occurrence of the woolly spider monkey (Brachyteles hypoxanthus). Ecol. Res. 25:25-32.

DEEM, S. L., KARESH, W. B. \& WEISMAN, W. 2001. Putting Theory into Practice: Wildlife Health in Conservation. Conservation Biology 15:1224-1233.

DILLON, A. \& KELLY, M. J. 2008. Ocelot home range, overlap and density: comparing radio telemetry with camera trapping. Journal of Zoology 275:391-398.

DILLON, A. \& KELLY, M. J. 2007. Ocelot Leopardus pardalis in Belize: the impact of trap spacing and distance moved on density estimates. Oryx 41:469-477.

EMMONS, L. H. 1988. A field study of ocelots (Leopardus pardalis) in Peru. Rev D’Ecologie, La Terre la Vie 43:133-157.

FILONI, C., CATÃO-DIAS, J. L., BAY, G., DURIGON, E. L., JORGE, R. S. P., LUTZ, H. \& HOFMANN-LEHMANN, R. 2006. First evidence of feline herpesvirus, calicivirus, parvovirus, and Ehrlichia exposure in Brazilian freeranging felids. Journal of Wildlife Diseases 42:470-7.

FIORELLO, C., ROBBINS, R., MAFFEI, L. \&WADE, S. 2006. Parasites of freeranging small canids and felids in the Bolivian Chaco. Journal of Zoo and Wildlife Medicine 37:130-134.

FIORELLO, C. V., NOSS, A. J., DEEM, S. L., MAFFEI, L. \& DUBOVI, E. J. 2007. Serosurvey of small carnivores in the Bolivian Chaco. Journal of Wildlife Diseases 43:551-7.

FLEMING, P. J. S., ALLEN, L. R., BERGHOUT, M. J., MEEK, P. D., PAVLOV, P. M., STEVENS, P., STRONG, K., THOMPSON, J. A. \& THOMSON, P. C. 1998. The performance of wild-canid traps in Australia: efficiency, selectivity and trap-related injuries. Wildlife Research 25:327-338.

HAINES, A., TEWES, M. \& LAACK, L. 2005. Survival and sources of mortality in ocelots. Journal of Wildlife Management 69:255-263.

HARVESON, P. M, TEWES, M. E., ANDERSON, G. L. \& LAACK, L. L. 2004. Habitat use by ocelots in south Texas: implications for restoration. Wildlife Society Bulletin 32:948-954.

INSTITUTO NACIONAL DE PESQUISAS ESPACIAIS [INPE]. 2014. Sistema Integrado de Dados Ambientais, Plataforma de coleta de dados 30800 - Parque Estadual do Rio Doce. $<$ http://sinda.crn2.inpe.br/PCD/historico/consulta_pcda. jsp>. Accessed 4 April 2014.

INTERNATIONAL UNION FOR CONSERVATION OF NATURE [IUCN]. 2015. Leopardus pardalis. <http://www.iucnredlist.org/search>. Accessed 12 January 2016.

JORGE, R. S. P., PEREIRA, M. S., MORATO, R. G., SCHEFFER, K. C., CARNIELI JR. P., FERREIRA, F. FURTADO, M. M., KASHIVAKURA, C. K., SILVEIRA, L., JACOMO, A. T. A., LIMA, E. S., PAULA, R. C. \& MAY-JUNIOR, J. A. 2010. Detection of rabies virus antibodies in Brazilian free-ranging wild carnivores. Journal of Wildlife Diseases 46:1310-1315.
KOLBE, J., SQUIRES, J. \& PARKER, T. 2003. An effective box trap for capturing lynx. Wildlife Society Bulletin 31:980-985.

KOLOWSKI, J. M. \& ALONSO, A. 2010. Density and activity patterns of ocelots (Leopardus pardalis) in northern Peru and the impact of oil exploration activities. Biological Conservation 143:917-925.

LIMA-BITTENCOURT, C. I., COSTA, P. S., BARBOSA, F. A., CHARTONE-SOUZA, E. \& NASCIMENTO, A. M. 2011. Characterization of a Chromobacterium haemolyticum population from a natural tropical lake. Letters in Applied Microbiology 52:642-50.

LOGAN, K. A, SWEANOR, L. L., SMITH, J. F. \& HORNOCKER, M. G. 1999. Capturing pumas with foot-hold snares. Wildlife Society Bulletin 27:201-208.

LUDLOW, M. \& SUNQUIST, M. 1987. Ecology and behavior of ocelots in Venezuela. National Geographic Research 3:447-461.

MCBRIDE-JR., R. \& MCBRIDE, R. 2007. Safe and selective capture technique for jaguars in the Paraguayan Chaco. Southwest Naturalist 52:570-577.

MCCARTHY, J., BELANT, J., BREITENMOSER-WURSTEN, C., HEARN, A. J. \& ROSS, J. 2013. Live trapping carnivores in tropical forests: tools and techniques to maximise efficacy. Raffles Bulletin of Zoology 28:55-66.

METZGER, B., PADUAN K, K. DOS SANTOS, RUBINI, A. S., DE OLIVEIRA, T. G. \& O'DWYER, L. H. 2008. The first report of Hepatozoon sp. (Apicomplexa: Hepatozoidae) in neotropical felids from Brazil. Veterinary Parasitology 152:28-33.

MICHALSKI, F, CRAWSHAW jr., P. G., DE OLIVEIRA, T. G., FABIÁN, M. E. 2007. Efficiency of box-traps and leg-hold traps with several bait types for capturing small carnivores (Mammalia) in a disturbed area of southeastern Brazil. Revista de Biologia Tropical. 55:315-20.

MOWAT, G., SLOUGH, B. \& RIVARD, R. 1994. A comparison of three live capturing devices for lynx: capture efficiency and injuries. Wildlife Society Bulletin 22:644-650

NEWSOME, A. E., CORBETT, L. K., CATLING, P. C., \& BURT, R. J. 1983. The Feeding Ecology of the Dingo. 1. Stomach Contents From Trapping in SouthEastern Australia, and the Non-Target Wildlife Also Caught in Dingo Traps. Australian Wildlife Research 10(3): 477 - 486

RABINOWITZ, A. 1990. Notes on the behavior and movements of leopard cats, Felis bengalensis, in a dry tropical forest mosaic in Thailand. Biotropica 22: 397-403.

ROCHA, F. L., ROQUE, A. L., ARRAIS, R. C., SANTOS, J. P., LIMAS VDOS, S., XAVIER, S. C., CORDEIR-ESTRELA, P., D’ANDREA, P. S. \& JANSEN, A. M. 2013. Trypanosoma cruzi TcI and TcII transmission among wild carnivores, small mammals and dogs in a conservation unit and surrounding areas, Brazil. Parasitology 140:160-170.

SHINDLE, D. B. \& TEWES, M. E. 2000. Immobilization of wild ocelots with tiletamine and zolazepam in southern Texas. Journal of Wildlife Diseases 36:546-50.

TERBORGH, J., LOPEZ, L., NUÑEZ, P., RAO, M., SHAHABUDDIN, G., ORIHUELA, G., RIVEROS, M., ASCANIO, R., ADLER, G. H., LAMBERT, T. D.\& BALBAS, L. 2001. Ecological meltdown in predator-free forest fragments. Science 294:1923-1926.

TIME AND DATE A.S. 2014. Moonrise, moonset and moon phases - Brasília, Brazil. http://www.timeanddate.com/moon/brazil/brasilia. Accessed 04 June 2014.

WIDMER, C. E., AZEVEDO, F. C. C., ALMEIDA, A. P., FERREIRA, F. \& LABRUNA, M. B. 2011. Tick-Borne Bacteria in Free-Living Jaguars (Panthera onca) in Pantanal, Brazil. Vector Borne Zoonotic Diseaes 11(8):1001-1005.

WIDMER, C. E., E. R. MATUSHIMA, F. C. C. AZEVEDO. 2016. Clinical Evaluation, Hematology and Serum Chemistry of Ocelots in the Atlantic Forest. Journal of Wildlife Disease 52(4): 916-921. 